\title{
'Sweetheart' Almond: A Fully Cross-compatible Pollenizer for the Early 'Nonpareil' Bloom that Exhibits Very High 'Marcona'-type Kernel Quality
}

\author{
Thomas Gradziel ${ }^{1}$ and Bruce Lampinen \\ Department of Plant Sciences, One Shields Avenue, University of California, \\ Davis, CA 95616
}

\section{Franz Niederholzer}

Colusa County Cooperative Extension, 100 Sunrise Boulevard, Suite E, P.O. Box 180, Colusa, CA 95965

\section{Mario Viveros \\ Kern County Cooperative Extension, 1031 South Mount Vernon Avenue, Bakersfield, CA 93307}

Additional index words. interspecific, introgression, pollenizer, 'Nonpareil', 'Marcona', oleic acid, roasting

'Sweetheart' is a new almond [Prunus dulcis Miller (D.A. Webb)] cultivar from the breeding program of the University of California at Davis, CA. 'Sweetheart' kernels have a cordate shape and very high oleic acid content and so are similar to the premium roasting quality Spanish cultivar Marcona but with a much higher kernel-to-nut ratio. 'Sweetheart' shows good overlap with the economically important early bloom of 'Nonpareil' and possessing a cross-incompatibility controlling S-genotype of $\mathrm{S}_{1} \mathrm{~S}_{14}$, it is fully cross-compatible with 'Nonpareil' $\left(\mathrm{S}_{7} \mathrm{~S}_{8}\right)$ and cross-compatible with all currently planted California almond cultivars except 'Winters' $\left(\mathrm{S}_{1} \mathrm{~S}_{14}\right)$. Trees have an upright and open architecture, which produce high yields with good year-to-year production consistency. The name 'Sweetheart' refers both to its high hearthealthy oleic acid content and its heart-shaped kernel.

\section{Origin}

The almond cultivar Sweetheart originated as a seedling from a cross between University of California at Davis (UCD) breeding selections SB3, 54-39E, and 2526 and was initially evaluated as selection SB13,36-52 (Fig. 1). The seedling's lineage includes the dominant California cultivar Nonpareil and Lukens Honey peach (Prunus persica Batsch) as a source of self-compatibility and disease resistance. Selection SB13,36-52 was selected for regional testing as an early

Received for publication 19 July 2013. Accepted for publication 29 Aug. 2013.

${ }^{1}$ To whom reprint requests should be addressed; e-mailtmgradziel@ucdavis.edu. bloom pollenizer for 'Nonpareil' based on its desirable early flowering and high kernel quality with an average kernel lipid content of $45 \%$ as well as a very high kernel oleic acid content of $71 \%$ when compared with $39 \%$ and $67 \%$, respectively, for 'Nonpareil' (Abdallah et al., 1998). California almond cultivars are self-incompatible and so selfsterile, requiring cross-compatible pollenizer cultivars for successful seed set. As a result of its productivity and desirable market quality, 'Nonpareil' currently comprises over $40 \%$ of the 162,000 ha of commercial production in California (Almond Board of California, 2012). The remaining cultivars are mainly planted as pollenizers for 'Nonpareil' with most initiating bloom after 'Nonpareil' and thus successfully covering the later bloom but leaving the early bloom vulnerable. Almond flower fecundity is highest in the early bloom, resulting in early pollenizers having high economic importance (Asai et al., 1996). Most early-flowering pollenizers, however, show inconsistent bloom overlap with 'Nonpareil' and a consequent lower production consistency for both cultivars (Micke et al., 1997). Flowering time in almond is determined by the accumulation of sufficient chilling units to overcome flower bud dormancy followed by the accumulation of sufficient heat units for bud development to flowering (Tabuenca et al., 1972). Requirements for both chilling and heat units differ among individual cultivars resulting in inconsistent year-to-year bloom overlap.

\section{Description}

The tree is upright and vigorous (Fig. 2). Production occurs on a combination of spurs and terminal shoots. This bearing habit results in high productivity with an open tree architecture that allows greater light penetration and air circulation to the canopy interior and so lower blossom and foliar disease. Flowers are numerous and produce abundant pollen. Kernels have a cordate shape (Fig. 3) and have both a high average kernel lipid content of $45 \%$ as well as a very high oleic acid content of $71 \%$ and so are similar to the premium roasting quality Spanish cultivar Marcona but with a much higher kernel-to-nut ratio (Table 1). 'Marcona' $\left(\mathrm{S}_{11} \mathrm{~S}_{12}\right)$ is a heavily planted cordate-shaped and self-incompatible cultivar in Spain and because of its very high oleic acid content $(\approx 70 \%)$ confers a high roasting quality (Socias i Company et al., 2008).

Self-incompatibility in almond is controlled by the gametophyte so that 'Nonpareil' $\left(\mathrm{S}_{7} \mathrm{~S}_{8}\right)$ will reject any pollen with a $\mathrm{S}_{7}$ or $\mathrm{S}_{8}$ genotype (Kester et al., 1994; López et al., 2006; Ortega et al., 2005). 'Sweetheart' has the S-genotype $\left(S_{1} S_{14}\right)$ and so is fully cross-compatible with 'Nonpareil' and is crosscompatible with all commercially planted almonds except the related UCD cultivar Winters $\left(\mathrm{S}_{1} \mathrm{~S}_{14}\right)$. Self-incompatibility in almond is variable with most commercial cultivars setting less than $10 \%$ of self-pollinated flowers and so considered self-incompatible (Weinbaum et al., 1989). Self-compatible cultivars need to set greater than $20 \%$ set after self-pollination to be considered commercially useful (López et al., 2006; Socias i Company et al., 2004). In a small number of cultivars, including 'Sweetheart' and 


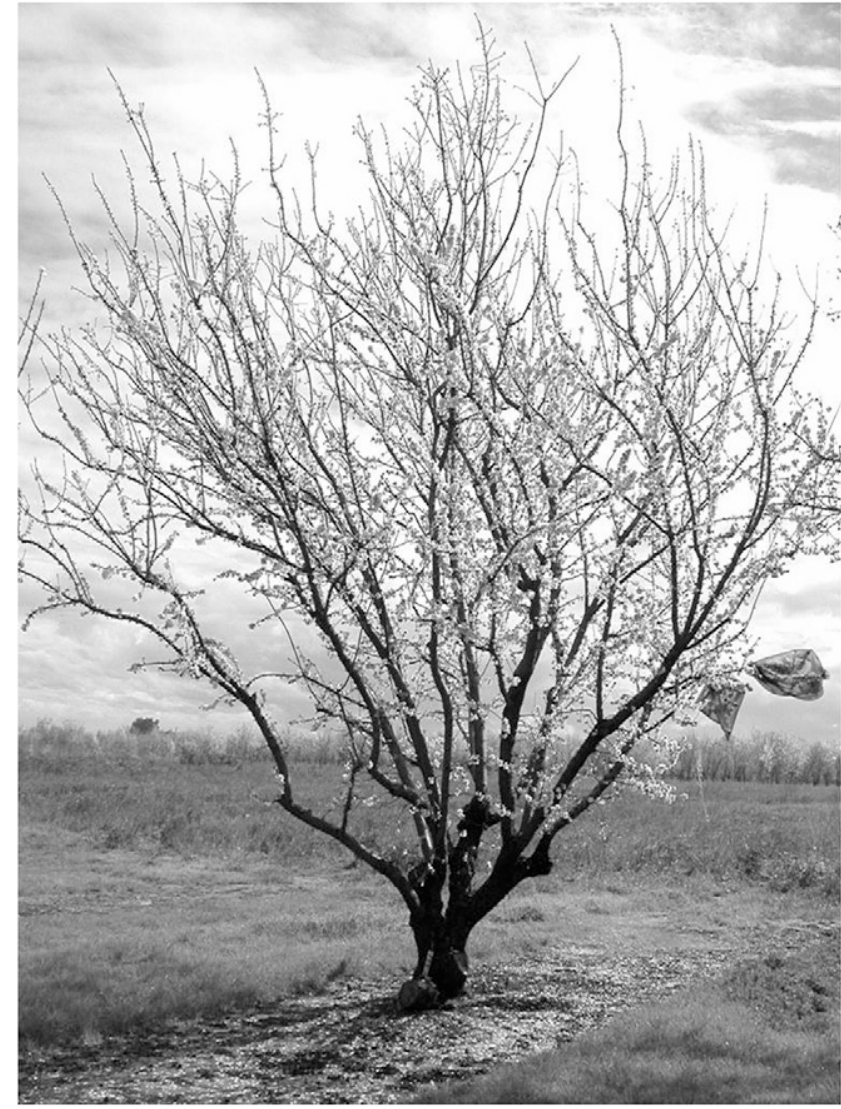

Fig. 2. Physical appearance of a 'Sweetheart' tree showing upright growth habit and prolific bloom.

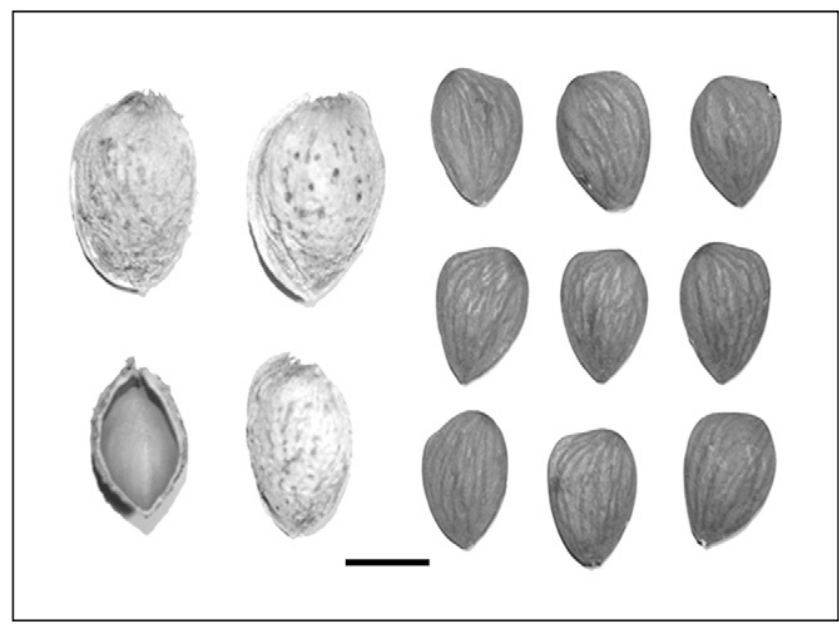

Fig. 3. Appearance of in-shell nut and kernels of 'Sweetheart' almond. Cross-section of empty shell at lower right shows thin but well-sealed shell. $B a r=1 \mathrm{~cm}$.

Table 1. Averaged 2010-12 production data for early-blooming almond cultivars compared with 'Nonpareil' in a 2004 grower test planting in Kern Co.

\begin{tabular}{lcccccc}
\hline Variety & Nuts/tree & $\begin{array}{c}\text { Kernel } \\
\text { mass }(\mathrm{g})\end{array}$ & $\begin{array}{c}\text { Kernel/nut } \\
\text { ratio }\end{array}$ & $\begin{array}{c}\text { Kernel } \\
(\mathrm{kg} / \text { tree })\end{array}$ & $\begin{array}{c}\text { Kernel } \\
\left(\mathrm{kg} \cdot \mathrm{ha}^{-1}\right)\end{array}$ & $\begin{array}{c}\text { Cumulative }(2006-12) \\
\text { kernel yield }\left(\mathrm{kg}^{-1} \mathrm{ha}^{-1}\right)\end{array}$ \\
\hline Nonpareil & $8,855 \mathrm{a}^{\mathrm{z}}$ & $1.18 \mathrm{bcd}$ & $0.70 \mathrm{a}$ & $10.4 \mathrm{ab}$ & $1,262 \mathrm{ab}$ & $22,220 \mathrm{a}$ \\
Sweetheart & $8,653 \mathrm{a}$ & $1.10 \mathrm{ef}$ & $0.68 \mathrm{a}$ & $9.6 \mathrm{abc}$ & $1,142 \mathrm{abc}$ & $18,437 \mathrm{~b}$ \\
Marcona & $6,449 \mathrm{~b}$ & $1.22 \mathrm{~b}$ & $0.28 \mathrm{~d}$ & $7.9 \mathrm{c}$ & $946 \mathrm{c}$ & $14,958 \mathrm{c}$ \\
Chips & $9,008 \mathrm{a}$ & $0.92 \mathrm{~h}$ & $0.65 \mathrm{ab}$ & $8.3 \mathrm{bc}$ & $998.4 \mathrm{bc}$ & $18,392 \mathrm{~b}$ \\
Kahl & $8,830 \mathrm{a}$ & $1.05 \mathrm{fg}$ & $0.62 \mathrm{~b}$ & $9.3 \mathrm{abc}$ & $1,118 \mathrm{abc}$ & $17,903 \mathrm{~b}$ \\
Kochi & $2,025 \mathrm{c}$ & $1.41 \mathrm{a}$ & $0.51 \mathrm{c}$ & $2.9 \mathrm{~d}$ & $346.1 \mathrm{~d}$ & $14,359 \mathrm{c}$ \\
\hline
\end{tabular}

${ }^{2}$ In each trait column, values with the same letter are not significantly different according to Duncan's test $(P \leq 0.05)$.
'Winters', the selfing percentage is between $10 \%$ and $20 \%$, which, although too low to be considered self-compatible, does confer greater crop stability when honeybee crosspollination is limiting (Gradziel, 2009).

\section{Performance}

'Sweetheart' along with 'Marcona' and other cultivar standards was evaluated in a replicated trial planted in 2004 in Kern County in the southern San Joaquin Valley. Data were collected from 2005 to 2012 for bloom and harvest period, nut yield and quality, and disease and insect damage. A number of smaller grower plantings at additional Sacramento and San Joaquin Valley sites were also used to verify replicated plot findings.

The combination of good bloom overlap with 'Nonpareil' (Fig. 4), open tree architecture, high flower density (Fig. 2), and partial self-compatibility has resulted in consistently high productivity over the 7 years of evaluation (Table 1). The thin "paper-shell" of 'Sweetheart' (Fig. 3) makes kernels more susceptible than 'Marcona' to damage by navel orangeworm (Amyelois transitella Walker), although insect damage was consistently under $5 \%$ for all test years. The kernel/ nut (kernel plus shell) harvest proportion of 0.68 , however, is more than double the 'Marcona' ratio of 0.28 (Table 1). The incidence of undesirable kernel types, particularly double kernels and kernels having multiple embryos, was consistently less than $5 \%$, being similar to 'Nonpareil'. The development of creases or folding of the kernel seedcoat, which is undesirable in the fresh market as well as for blanched kernels, was also very low in 'Sweetheart'. Nuts and kernels of 'Sweetheart' were also similar to 'Marcona' in cordate shape; however, under intensive California cultivation, 'Sweetheart' produces a slightly more angular and smaller kernel than 'Marcona' (Table 1). Harvest of 'Sweetheart' is just after the dominant cultivar Nonpareil, which promotes more efficient use of harvesting equipment (Fig. 4). 'Sweetheart' trees showed moderately susceptibility to almond hull rot (Rhizopus spp. and Monilinia spp.), being similar to 'Nonpareil' with less than 100 shoot strikes per tree observed in high disease years as compared with over 500 strikes per tree observed in susceptible control cultivars.

\section{Availability}

'Sweetheart' is available as a patented (U.S. Plant Patent 19436 P3) cultivar with licenses granted through the University of California Technology Transfer Services, 1850 Research Park Drive, Suite 100, Davis, CA 95618-6134. Propagation material is distributed as a registered virus tested source through the Foundation Plant Service (FPS), University of California, 1 Shields Avenue, Davis, CA 95616. A virus tested and unpatented source of the Marcona cultivar has also been made available through FPS. 


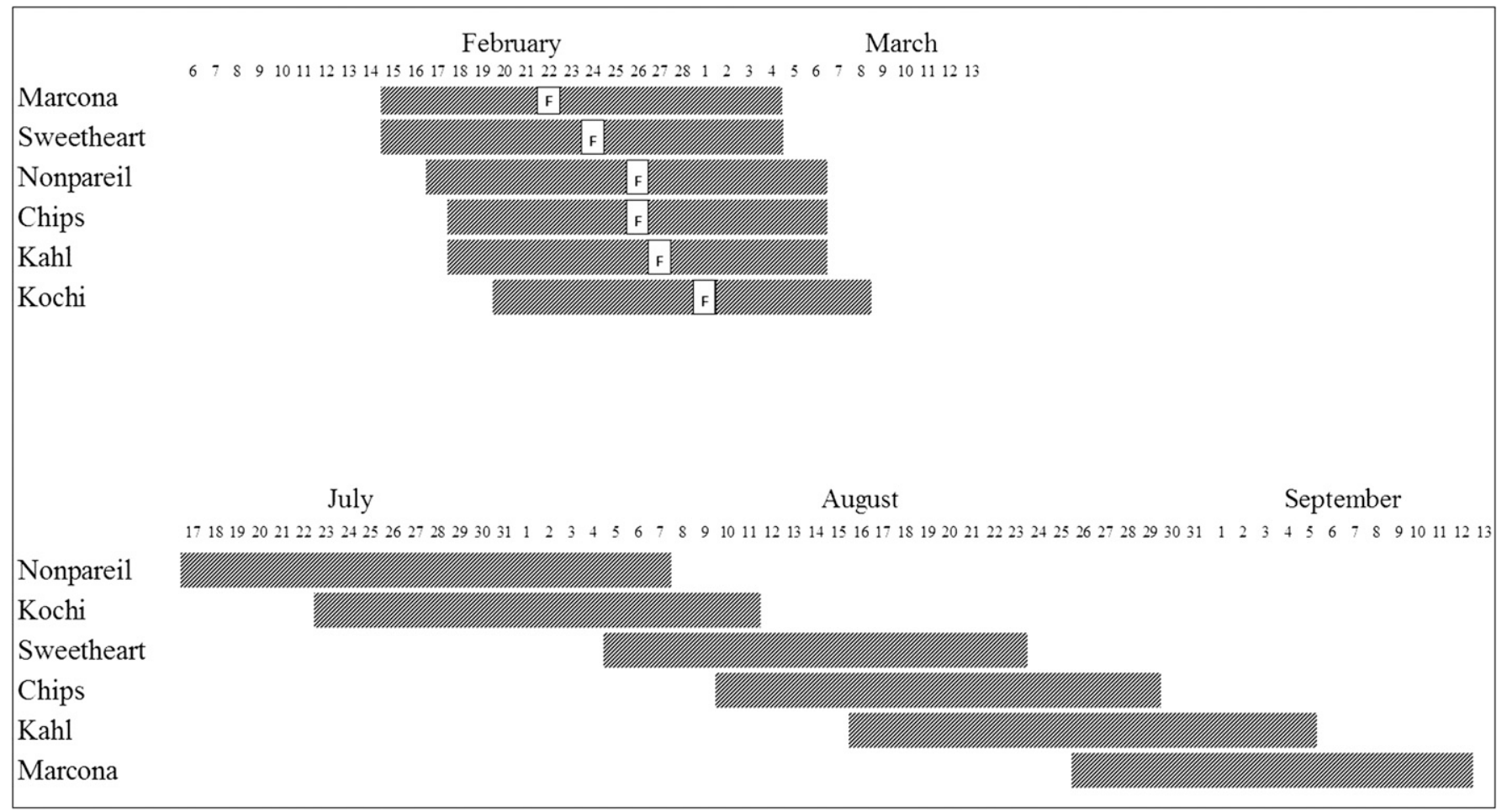

Fig. 4. Average (2006-12) bloom and hull-split dates for the Kern Co. trial. (Top) Bar chart plots onset of bloom to $100 \%$ petal fall. "F" indicates full bloom. (Bottom) Average hull-split progression from date of initial splitting to full split.

\section{Literature Cited}

Abdallah, A., M.H. Ahumada, and T.M. Gradziel. 1998. Oil content and fatty acid composition of almond kernels from different genotypes and California production regions. J. Amer. Soc. Hort. Sci. 123:1029-1033.

Almond Board of California. 2012. Almond almanac. Modesto, CA. <http://www.lefigaro.fr/assets/ pdf/2012\%20Almond\%20AlmanacFINAL. pdf>.

Asai, W.K., W.C. Micke, D.E. Kester, and D. Rough. 1996. The Evaluation and selection of current varieties, p. 52-60. In: Micke, W.C. (ed.). Almond production manual. Publication 3364, University of California, Division of Agriculture and Natural Resources, Oakland, CA.

Gradziel, T.M. 2009. Almond (Prunus dulcis) breeding, p. 1-31. In: Jain, S.M. and M. Priyadarshan (eds.). Breeding of plantation tree crops. Springer Science, New York, NY.

Kester, D.E., T.M. Gradziel, and W.C. Micke. 1994. Identifying pollen incompatibility groups in California almond cultivars. J. Amer. Soc. Hort. Sci. 119:106-109.

López, M., F.J. Vargas, and I. Battle. 2006. Self(in)compatibility almond genotypes: A review. Euphytica 150:1-15.

Micke, W.C., D.E. Kester, T.M. Gradziel, J.T. Yeager, M.A. Thorpe, J.H. Connell, P.S. Verdegaal, and M. Viveros. 1997. Almond cultivar evaluation using regional trials. Acta Hort. 470:91-94.

Ortega, E., B.G. Sutherland, F. Dicenta, R.I Bošković, and K.R. Tobutt. 2005. Determination of incompatibility genotypes in almond using first and second intron consensus primers: Detection of new $\mathrm{S}$ alleles and correction of reported S genotypes. Plant Breed. 124:188196.

Socias i Company, R., J.M. Alonso, and J. Gómez Aparisi. 2004. Fruit set and productivity in almond as related to self-compatibility, flower morphology and bud density. J. Hort. Sci. Biotechnol. 79:754-758.

Socias i Company, R., O. Kodad, J.M. Alonso, and T.M. Gradziel. 2008. Almond quality: A breeding perspective. In: Janick, J. (ed.). Hort. Revi. 34:197-238.

Tabuenca, M.C., M. Mut, and J. Herrero. 1972. Influence of temperature on the flowering time of almonds. Ann Aula Dei 11:378-395 [in Spanish].

Weinbaum, S.A., D.V. Shaw, and T.T. Muroka. 1989. Independence of self-compatibility and potentiality for self-pollination in peach $x$ almond hybrids. Euphytica 41:53-58. 